\title{
DEVELOPING GRADUATE ATTRIBUTES USING A SUSTAINABILITY ASSESSMENT PROJECT
}

\author{
Ralph Buchal ${ }^{1}$ and Emmanuel Songsore ${ }^{2}$ \\ ${ }^{1}$ Western University, ${ }^{2}$ Wilfred Laurier University \\ rbuchal@uwo.ca
}

\begin{abstract}
Ashby's sustainability assessment method provides a systematic framework for dealing with complex, multidisciplinary problems. It also provides a framework for helping graduate students develop many desired graduate attributes. In this study, Ashby's method was used in a third-year group sustainability assessment project, after which the development of three Canadian Engineering Accreditation Board graduate attributes (i.e., professionalism, impact on society and the environment, and life-long learning) were assessed. Students were surveyed to self-assess their level of competence in selected graduate attribute indicators, using Western Engineering programs' Graduate Attributes indicators and rubric. After completing the project, most students assessed their abilities to be good to excellent under most indicators. Students also rated the project as being effective in developing these attributes.
\end{abstract}

Keywords: Sustainability, graduate attributes

\section{INTRODUCTION}

A well-rounded engineer must develop competence in several areas beyond mastery of technical knowledge. This has been recognized by the Canadian Engineering Accreditation Board (CEAB) which states:

\footnotetext{
The engineering profession expects of its members competence in engineering as well as an understanding of the effects of engineering on society. Thus, accredited engineering programs must contain not only adequate mathematics, science, and engineering curriculum content but must also develop communication skills, an understanding of the environmental, cultural, economic, and social impacts of engineering on society, the concepts of sustainable development, and the capacity for life-long learning. [1]
}

To ensure that engineering graduates are adequately prepared to practice as professional engineers, CEAB requires that all graduates of accredited engineering programs in Canada have developed and demonstrated competency in twelve graduate attributes. Each engineering program in Canada is free to develop its own detailed indicators to be used for defining and assessing the top-level attributes as prescribed by CEAB. Programs are required to develop and use indicators to assess these graduate attributes and use this information to continuously improve curriculum.

Among these attributes, some are addressed in only a few courses in most engineering curricula. These include Professionalism, Impact of Engineering on Society and the Environment, and Life-Long Learning. In particular, impact of engineering on society and the environment is tends to be a weakness in most educational contexts [2][3][4].

One way to assess outcomes is by the use of surveys to assess student perception of their competency in each of the graduate attributes [2][3][5]. It is worth noting that the same care is needed in developing valid indicators for assessing graduate attributes. In many cases the indicators used by programs have not been rigorously tested for validity. In this study, the indicators developed by Western University are used without any claims regarding validity.

\section{SUSTAINABILITY ASSESSMENT METHOD}

The sustainability assessment method developed by Ashby et al. [6], [7] provides a systematic framework for dealing with complex, multidisciplinary problems, and promotes a systems-thinking approach (Figure 1). The method is used to assess the sustainability of a proposed solution. The method consists of five stages: problem definition, stakeholder analysis, fact-finding, synthesis and evaluation, and reflection. The problem definition stage defines the objectives, scope and time scale of a proposed solution to be assessed. Stakeholder analysis identifies the stakeholders and their concerns. The fact-finding stage gathers factual information in several categories: materials, energy, environment, legislation and regulations, economics and society. This ensures that all perspectives are considered. The synthesis and evaluation stage uses the facts along with argumentation, judgement and reasoning to assess the positive and negative impacts on environmental, economic and social sustainability. These are classified as natural capital (planet), manufactured 
capital (prosperity) and human capital (people). The reflection stage reflects on the positive and negative impacts and reaches conclusions about whether the objective is achievable, and whether the benefits outweigh the negative impacts. Reflection also suggests new or different ways to achieve the objective.

Ashby's sustainability method maps directly to several CEAB graduate attributes [1], particularly professionalism, impact of engineering on society and the environment, and life-long learning.

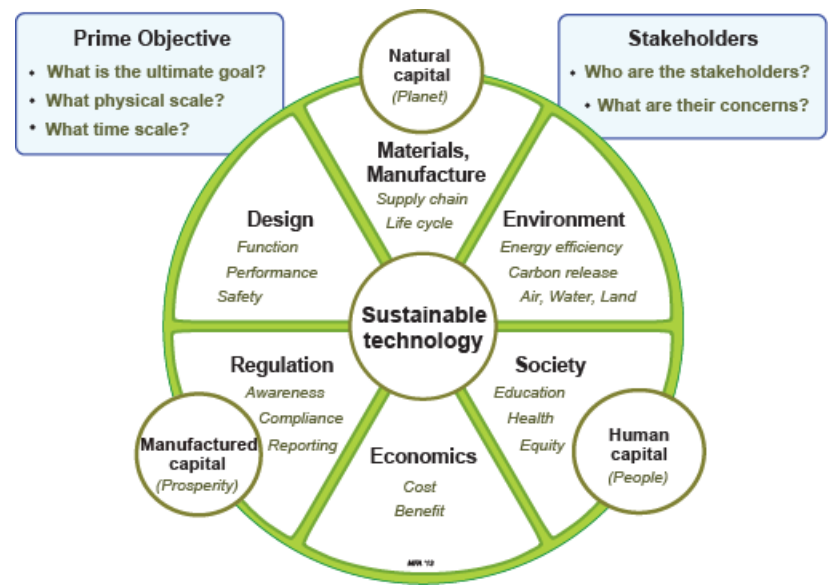

Figure 1. Ashby's Sustainability Assessment Framework [6].

Ashby's method is intended to be used in conjunction with the CES Edupack material selection software [8]. CES Edupack includes searchable databases of nations of the world, legislation and regulations, energy storage systems, low carbon power systems, and nuclear energy systems. The nations of the world database includes a variety of information about every nation in the world. The information is grouped into several categories: demographic information, education, human rights and governance, economy and development, health, energy, carbon and environment, and military expenditures. The low carbon power database contains a description, resource intensity, operational parameters, and status of most if not all power generation technologies. These technologies include: conventional fossil fuels, fuel cells, geothermal, hydro, nuclear, biomass, solar, wind, wave, and tidal.

\section{DESCRIPTION OF COURSE PROJECT}

A sustainability assessment project was introduced in Fall 2017 in a third-year materials selection course in the mechatronics systems engineering program at Western University. The overall project objective was to "reduce carbon emissions enough to avoid the worst consequences of climate change. "Students worked in groups to carry out a sustainability assessment of a solution of their choice. In some cases, they chose solutions to other environmental issues. Solutions that they assessed included: clean meat, biodegradable plastics, geothermal power, wave power, microgrid power, nuclear power, conflict minerals in electronics, sustainable freight trains, delivery drones, sustainable clothing, afforestation, and Elon Musk's traffic tunnels. There were 17 teams of 3-5 students each.

\section{METHODOLOGY}

While the projects demonstrated the development of most if not all the CEAB graduate attributes, three attributes in particular were assessed: professionalism, impact of engineering on society and the environment, and life-long learning. Elements of the sustainability assessment project mapped very well to many of the Graduate Attribute indicators defined by the Faculty of Engineering at Western University.

Upon completing the course, online surveys were conducted to assess student perceptions of their current competence level according to selected graduate attribute indicators, as well as their assessment of the value of the sustainability project in developing those attributes.

The student participation rate in the survey was disappointingly low. Eight students agreed to participate. Due to the small sample size, the results can only be considered to be very preliminary.

\section{PROFESSIONALISM}

CEAB defines professionalism as:

An understanding of the roles and responsibilities of the professional engineer in society, especially the primary role of protection of the public and the public interest [1].

The indicators for professionalism developed by Western's Faculty of Engineering and the corresponding descriptor for "good" performance are shown in Table 1.

Table 1. Western's graduate attribute indicators for professionalism, and descriptors for "good" performance.

\begin{tabular}{|l|l|}
\hline Western GA indicator & Descriptor for "Good" \\
\hline $\begin{array}{l}\text { Recognizes role of } \\
\text { protection of public. }\end{array}$ & $\begin{array}{l}\text { I recall AND comprehend } \\
\text { role of protection of the } \\
\text { public and public. }\end{array}$ \\
\hline Stakeholder engagement. & $\begin{array}{l}\text { I typically determine the } \\
\text { interests and objectives of } \\
\text { stakeholders. }\end{array}$ \\
\hline $\begin{array}{l}\text { Recognizes limitations of } \\
\text { regulations, codes and } \\
\text { technically based } \\
\text { analysis in a societal } \\
\text { context. }\end{array}$ & $\begin{array}{l}\text { I acknowledge the } \\
\text { limitations of regulations } \\
\text { and codes. }\end{array}$ \\
\hline
\end{tabular}


Table 2 shows the mapping of a subset of Western's graduate attribute indicators for professionalism to elements of the sustainability assessment project. In particular, Ashby's method provides detailed guidance for identifying stakeholders and their concerns.

Table 2. Comparison of Western's graduate attribute indicators for professionalism, and the corresponding elements of the sustainability assessment project.

\begin{tabular}{|l|l|}
\hline Western GA indicator & $\begin{array}{l}\text { Sustainability assessment } \\
\text { project }\end{array}$ \\
\hline $\begin{array}{l}\text { Recognizes role of } \\
\text { protection of public. }\end{array}$ & $\begin{array}{l}\text { Fact-finding under the } \\
\text { "society" category. } \\
\text { Impacts on environmental, } \\
\text { economic and social } \\
\text { sustainability. }\end{array}$ \\
\hline Stakeholder engagement. & $\begin{array}{l}\text { Identifying stakeholders } \\
\text { and their concerns. }\end{array}$ \\
\hline $\begin{array}{l}\text { Recognizes limitations of } \\
\text { regulations, codes and } \\
\text { technically based } \\
\text { analysis in a societal } \\
\text { context. }\end{array}$ & $\begin{array}{l}\text { Fact-finding under the } \\
\text { "legislation and } \\
\text { regulations" category. }\end{array}$ \\
Impact of legislation and \\
regulations on \\
sustainability.
\end{tabular}

\subsection{Survey Questions}

Students were asked to assess their current level of competence in the three GA indicators, on a 4-point Likert scale from $1=$ poor to $4=$ Excellent. Each question included a short description of where the GA is addressed in the project to prompt student reflection.

- Recognizes role of protection of the public. Protection of the public interest is addressed in the sustainability assessment project by fact-finding under the "society" category, and in considering impacts on human and social capital.

- Stakeholder engagement. Stakeholder engagement is addressed in the sustainability assessment project by the stakeholder analysis phase of the project.

- Recognizes limitations of regulations, codes and technically based analysis in a societal context. These limitations are considered in the sustainability assessment project by considering the impact of legislation and regulations on human and social capital.

Students were then asked about the effectiveness of the sustainability assessment project in helping them improve and/or practice these attributes.

\subsection{Results}

Students rated their abilities in the three indicators to be good to excellent after completing the project (Figure 2). They rated their ability in stakeholder engagement higher than the other GAs.

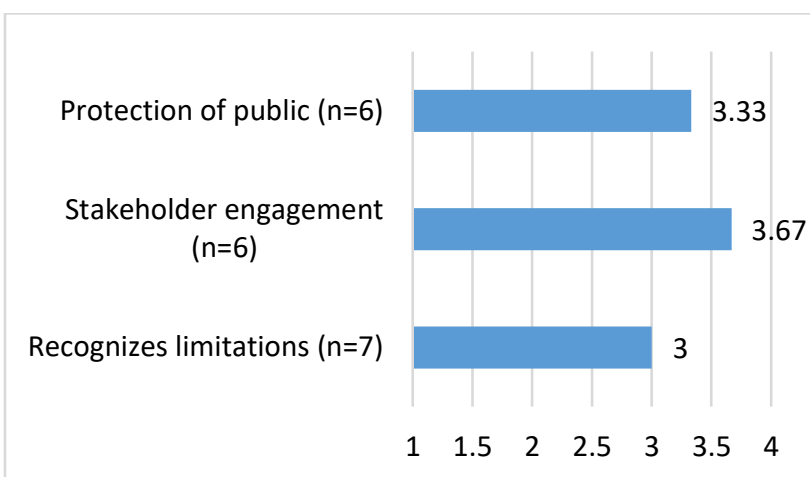

Figure 2. Self-assessment of abilities in professionalism. 1=poor, 2=below average, $3=$ good, $4=$ excellent.

Students rated the project as being moderately to very effective in developing these abilities $(n=6)$ as shown in Figure 3. In particular three out of six students rated the project as being extremely effective in developing stakeholder engagement.

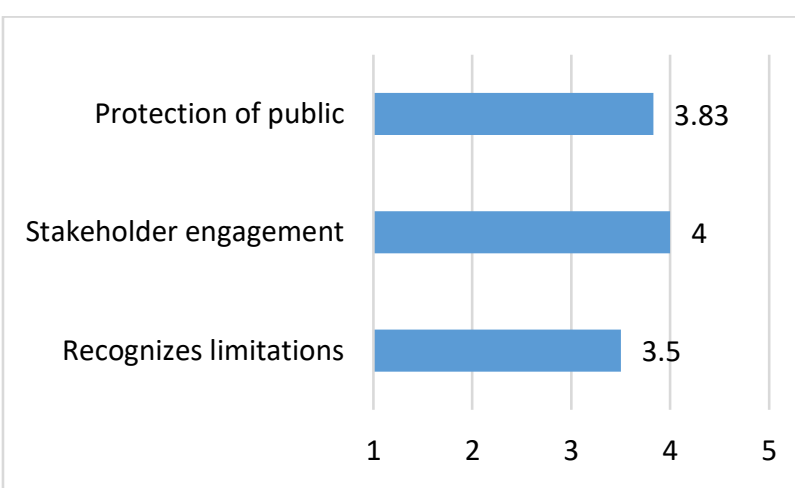

Figure 3. Assessment of effectiveness of project in developing professionalism attributes $(n=6)$. $1=$ not effective, 2 =slightly effective, $3=$ moderately effective, $4=$ very effective, $5=$ extremely effective.

\section{IMPACT OF ENGINEERING ON SOCIETY AND THE ENVIRONMENT}

$\mathrm{CEAB}$ defines impact of engineering on society and the environment as:

An ability to analyze social and environmental aspects of engineering activities. Such ability includes an understanding of the interactions that engineering has with the economic, social, health, safety, legal, and cultural aspects of society, the uncertainties in the prediction of such interactions; and the concepts of 
sustainable design and development and environmental stewardship [1].

The indicators developed by Western's Faculty of Engineering for impact of engineering on society and the environment and the corresponding descriptor for "good" performance are shown in Table 3.

Table 3. Western's graduate attribute indicators for impact of engineering on society and the environment, and descriptors for "good" performance.

\begin{tabular}{|l|l|}
\hline Western GA indicator & Descriptor for "good" \\
\hline $\begin{array}{l}\text { An understanding of the } \\
\text { interactions that } \\
\text { engineering has with the } \\
\text { economic, social, health, } \\
\text { safety, legal, and cultural } \\
\text { aspects of society, the } \\
\text { uncertainties in the } \\
\text { prediction of such } \\
\text { interactions. }\end{array}$ & $\begin{array}{l}\text { I accurately the impact of } \\
\text { engineering on the } \\
\text { economic (social, health } \\
\text { and safety, legal, cultural) } \\
\text { aspects of society. }\end{array}$ \\
\hline $\begin{array}{l}\text { Concepts of sustainable } \\
\text { design and development } \\
\text { and environmental } \\
\text { stewardship. }\end{array}$ & $\begin{array}{l}\text { I appropriately quantify } \\
\text { and address sustainable } \\
\text { design and development } \\
\text { (or environmental } \\
\text { stewardship) in } \\
\text { engineering solutions. }\end{array}$ \\
\hline
\end{tabular}

Table 4 shows the mapping of a subset of Western's graduate attribute indicators to elements of the sustainability assessment project.

Table 4. Comparison of Western's graduate attribute indicators for impact of engineering, and the corresponding elements of the sustainability assessment project.

\begin{tabular}{|l|l|}
\hline Western GA indicator & $\begin{array}{l}\text { Sustainability } \\
\text { assessment project }\end{array}$ \\
\hline $\begin{array}{l}\text { An understanding of the } \\
\text { interactions that } \\
\text { engineering has with the } \\
\text { economic, social, health, } \\
\text { safety, legal, and cultural } \\
\text { aspects of society, the } \\
\text { uncertainties in the } \\
\text { prediction of such } \\
\text { interactions. }\end{array}$ & $\begin{array}{l}\text { Impacts on } \\
\text { and social sustainability. }\end{array}$ \\
\hline $\begin{array}{l}\text { Concepts of sustainable } \\
\text { design and development } \\
\text { and environmental } \\
\text { stewardship. }\end{array}$ & $\begin{array}{l}\text { Impacts on environmental } \\
\text { sustainability. }\end{array}$ \\
\hline
\end{tabular}

\subsection{Survey Questions}

Students were asked to assess their current level of competence in six Western Engineering GA indicators, on a 4-point Likert scale from 1=poor to 4=Excellent. Each question included a short description of where the GA is addressed in the project to prompt student reflection.

- $\quad$ Ability to analyse the interactions of engineering with the economic aspects of society. This is addressed in the sustainability assessment project when considering impacts on manufactured capital.

- Ability to analyse the interactions of engineering with the social and cultural aspects of society.

- Ability to analyse the interactions of engineering with the legal aspects of society. This is addressed in the sustainability assessment project when considering impacts of legislation and regulation on the three capitals, particularly human and social capital.

- Ability to analyse the interactions of engineering with the health and safety aspects of society.

- Demonstrate understanding of the concept of sustainable design and development. This is addressed in the sustainability assessment project when considering impacts on the three capitals, particularly natural capital.

- Demonstrate understanding of the concept of environmental stewardship. This is addressed in the sustainability assessment project when considering impacts on the three capitals, particularly natural capital.

Student were then asked about the effectiveness of the sustainability assessment project in improving and/or practicing these attributes.

\subsection{Results}

After completing the project, students rated their abilities sustainable design, and environmental stewardship, to be good to excellent (Figure 4). Their understanding of economic, social and cultural, and health and safety aspects was rated as good. They rated their understanding of legal aspects lower than the other attributes.

Understanding of legal aspects of engineering is probably a particular challenge in our engineering curricula. It is worth noting that Ashby's sustainability assessment method explicitly includes consideration of laws and regulations, and the supporting CES software contains a regulations database. However, this did not seem to resonate strongly with students. 


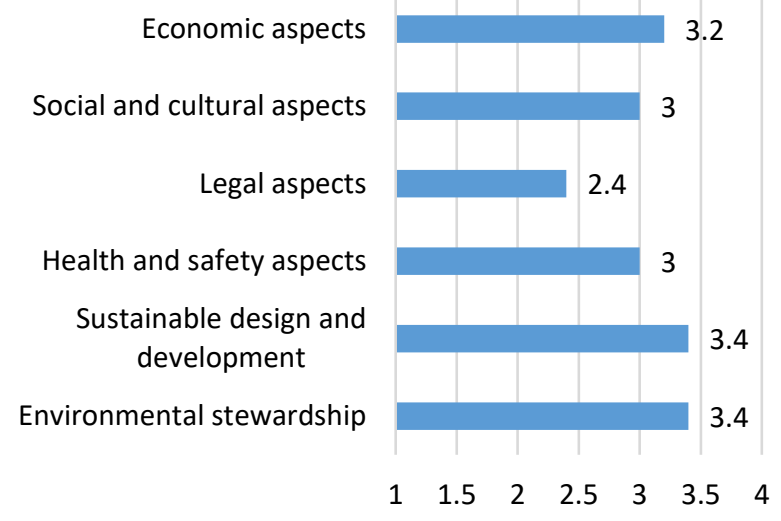

Figure 4. Self-assessment of abilities in impact of engineering on society and the environment $(n=5)$. 1 =poor, $2=$ below average, 3 =good, $4=$ excellent.

Students rated the project as being moderately to very effective in developing their understanding of economic, social and cultural, legal, and health and safety aspects of engineering $(n=5)$, as shown in Figure 5. They rated the project as being very to extremely effective in developing their understanding of sustainable design and development, and environmental stewardship. Notably, all respondents $(n=5)$ considered the project to be extremely effective in developing their understanding of sustainable design and development, which is the central theme of the project and Ashby's method.

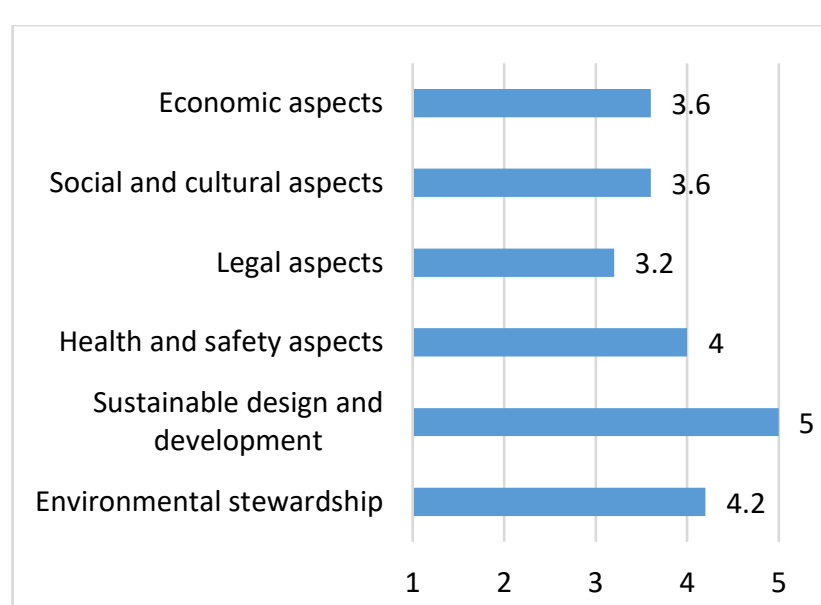

Figure 5. Assessment of effectiveness of project in developing impact of engineering attributes $(n=5) .1=$ not effective, 2 =slightly effective, $3=$ moderately effective, $4=$ very effective, $5=$ extremely effective.

\section{LIFE-LONG LEARNING}

CEAB defines life-long learning as:

An ability to identify and to address their own educational needs in a changing world in ways sufficient to maintain their competence and to allow them to contribute to the advancement of knowledge [1].

The indicators developed by Western's Faculty of Engineering for life-long learning and the corresponding descriptor for "good" performance are shown in Table 5.

Table 5. Western's graduate attribute indicators for life-long learning, and descriptors for "good" performance.

\begin{tabular}{|l|l|}
\hline Western GA indicator & Descriptor for "good" \\
\hline $\begin{array}{l}\text { personal educational } \\
\text { needs in a changing } \\
\text { world. }\end{array}$ & $\begin{array}{l}\text { I am willing to identify and } \\
\text { address gaps in my } \\
\text { knowledge to respond to a } \\
\text { specific problem or issue. }\end{array}$ \\
\hline Use of reflection. & $\begin{array}{l}\text { I reflect successfully to } \\
\text { identify personal strengths } \\
\text { and weaknesses } \\
\text { objectively. }\end{array}$ \\
\hline $\begin{array}{l}\text { Ability to apply critical } \\
\text { analysis. }\end{array}$ & $\begin{array}{l}\text { I am capable of } \\
\text { consistently and accurately } \\
\text { critically evaluating } \\
\text { information for authority, } \\
\text { currency and objectivity. }\end{array}$ \\
\hline $\begin{array}{l}\text { Organization of } \\
\text { knowledge. }\end{array}$ & $\begin{array}{l}\text { I am able to organize } \\
\text { knowledge independently } \\
\text { AND sufficiently clearly } \\
\text { that such materials are } \\
\text { readily understood by } \\
\text { others. }\end{array}$ \\
\hline Learn independently. & $\begin{array}{l}\text { I am able to learn } \\
\text { independently within fields } \\
\text { that have previously been } \\
\text { learned at a less- } \\
\text { challenging level. }\end{array}$ \\
\hline
\end{tabular}

Table 6 shows the mapping of a subset of Western's graduate attribute indicators to elements of the sustainability assessment project.

Table 6. Comparison of Western's graduate attribute indicators for life-long learning, and the corresponding elements of the sustainability assessment project.

\begin{tabular}{|l|l|}
\hline Western GA indicator & $\begin{array}{l}\text { Sustainability assessment } \\
\text { project }\end{array}$ \\
\hline $\begin{array}{l}\text { Motivation to identify } \\
\text { personal educational } \\
\text { needs in a changing } \\
\text { world. }\end{array}$ & $\begin{array}{l}\text { Fact-finding and } \\
\text { background research stage. }\end{array}$ \\
\hline Use of reflection. & Reflection on results. \\
\hline $\begin{array}{l}\text { Ability to apply critical } \\
\text { analysis. }\end{array}$ & $\begin{array}{l}\text { Fact-finding and } \\
\text { background research stage, } \\
\text { when evaluating the quality } \\
\text { of information found from } \\
\text { different sources. }\end{array}$ \\
\hline
\end{tabular}




\begin{tabular}{|l|l|}
\hline $\begin{array}{l}\text { Organization of } \\
\text { knowledge. }\end{array}$ & $\begin{array}{l}\text { Fact-finding and } \\
\text { background research stage, } \\
\text { where facts and objective } \\
\text { knowledge are categorized. }\end{array}$ \\
& $\begin{array}{l}\text { Evaluation and synthesis } \\
\text { phase, when information } \\
\text { and knowledge is } \\
\text { organized and linked to } \\
\text { support conclusions and } \\
\text { recommendations. }\end{array}$ \\
\hline Learn independently. & $\begin{array}{l}\text { Problem definition, } \\
\text { stakeholder analysis and } \\
\text { fact-finding phases, when } \\
\text { identifying and learning } \\
\text { about the issues and facts } \\
\text { related to a chosen topic. }\end{array}$ \\
\hline
\end{tabular}

After the completion of the project, students rated their abilities to be good to excellent in all attributes (Figure 6).

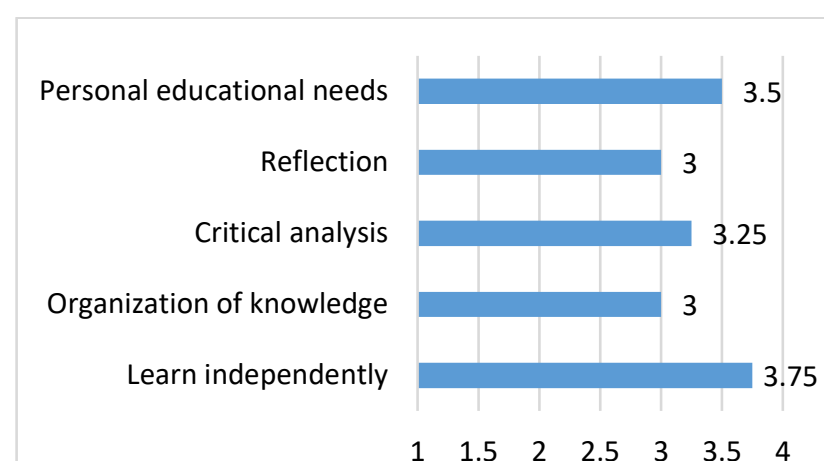

Figure 6. Self-assessment of abilities in life-long learning $(n=4)$. $1=$ poor, $2=$ below average, $3=$ good, $4=$ excellent.

Students rated the project as being very effective to extremely effective in developing all of the attributes (Figure 7).

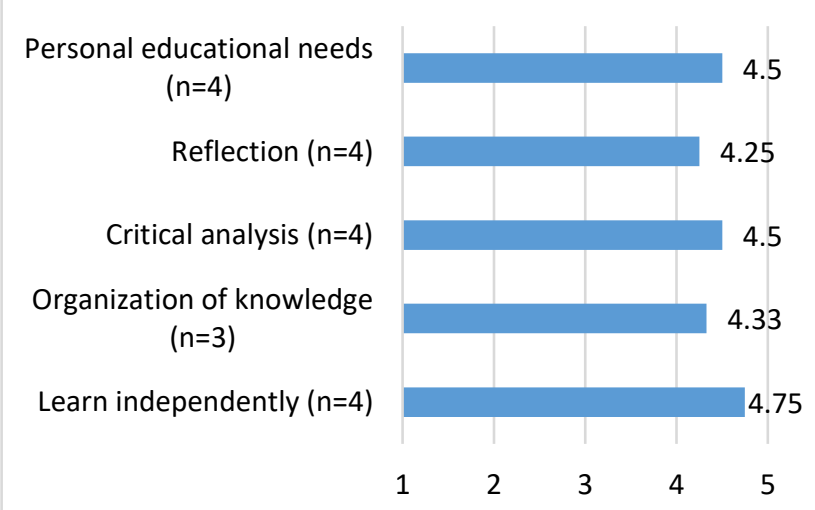

Figure 7. Assessment of effectiveness of project in developing life-long learning attributes. 1=not effective,

\author{
2 =slightly effective, $3=$ moderately effective, $4=$ very \\ effective, $5=$ extremely effective.
}

\section{DISCUSSION AND CONCLUSIONS}

After the completion of group projects using Ashby's sustainability assessment method, most students rated their ability as good to excellent for most of the measured CEAB graduate attribute indicators for professionalism, impact of engineering on society and the environment, and life-long learning. The respondents also found the sustainability project to be slightly effective to very effective in developing most of the identified indicators. Respondents were unanimous in saying that the project was extremely effective in developing their understanding of sustainable design and development. Most responses on the effectiveness of the project in developing life-long learning skills (identifying personal educational needs, reflection, critical analysis, organization of knowledge, and independent learning) ranged between very and extremely effective. Furthermore, the resulting group reports met or exceeded the professor's expectations in all the graduate attribute indicators being assessed.

The graduate attributes considered in this study (professionalism, impact of engineering on society and the environment, and life-long learning) have been difficult for engineering educators to define, measure, and develop in the curriculum. This study suggests that a framework like Ashby's sustainability assessment method can provide an effective way to develop these key attributes. Further, student surveys are one way to assess student competency in these attributes. This study highlights the importance of using well-structured framework in designing all aspects of curriculum (including assessments) in ways that ensure students are developing specific skills and abilities. It also reinforces the importance of measuring learning outcomes that reflect various desired educational goals (i.e., graduate attributes). For example, students' struggles with the legal aspects of sustainability stood out as a challenge in this study. Yet, this challenge was not anticipated by the instructor. In carrying out such assessments, instructors could better understand student learning and structure curriculum to support students in areas of weakness.

Due to the small sample size in this study, the results are only preliminary. Further studies with larger sample size are needed to develop a more holistic and comprehensive understanding of graduate attribute development. These attributes should also be measured in other aspects of curriculum such as teaching, exams and tutorials to better understand how these together contribute to student development.

\section{ACKNOWLEDGEMENTS}

The authors wish to acknowledge the support of Western's Teaching Fellowship, and the Centre for 
Teaching and Learning, for sponsoring and assisting with this project.

\section{REFERENCES}

[1] 2017 Accreditation Criteria and Procedures. Canadian Engineering Accreditation Board, 2017.

[2] J. S. Cicek, P. Labossiere, and D. Mann, "Surveying fourth year engineering student perceptions of graduate attribute competencies," Proceedings of the Canadian Engineering Education Association (CEEA), 2013.

[3] J. S. Cicek, P. Labossiere, and S. Ingram, "Examining fourth year engineering student perceptions of graduate attribute competencies: Year three," Proceedings of the Canadian Engineering Education Association (CEEA), 2015.

[4] D. S. Petkau, "Industry perceptions of graduate attribute competencies," Proceedings of the Canadian Engineering Education Association (CEEA), 2015.

[5] M. Wright, C. Campbell, S. Nesbit, T. Froese, and S. Wilton, "Student Perspectives on Graduate Attributes," Proceedings of the Canadian Engineering Education Association (CEEA), 2013.

[6] M. Ashby, D. Ferrer, and J. Bruce, "Materials and Sustainable Development-a White Paper," Granta Design, Cambridge ( www. grantadesign. com/education/), 2013.

[7] M. Ashby and T. Vakhitova, "Active-Learning Took Kit - Sustainable Development," Granta Design, Cambridge ( www. grantadesign. com/education/), 2017.

[8] "What is CES Edupack." [Online]. Available: http://www.grantadesign.com/education/edupack/. [Accessed: 04-May-2018] 